\title{
Bortom \\ kärnfamiljen? \\ Omsorgsgörande från barns perspektiv
}

\section{Af SARa Eldén}

\begin{abstract}
Beyond the nuclear family? Care from the perspectives of children

Research on children and care often takes its point of departure in assumptions about the nuclear family as the hub of care. In contrast, this study, by taking its point of departure in the actual practices and relations of care that children experience and engage in - accessed through children's own narratives of everyday care - suggests new ways of understanding children and care. There is an 'ordinary complexity of care' it is argued, apparent in the presence of 'others' than parents - e.g., grandparents, siblings, friends, neighbours - doing care in children's lives. The study also shows how the doing of care still is a gendered activity that seems to extend to female carers outside the nuclear family. Also, children's own doing of care emerges, a doing that poses critical questions regarding children as 'competent actors'.
\end{abstract}

\section{KEYWORDS}

care, care practices, agency, child, family practices, qualitative method

Sara Elden er lektor i sociologi ved Linnaeus University, Växjö, og forsker i familie- og omsorgspraksisser. I sit aktuelle projekt har Elden fokus på familiepraksisser og betalt børnepasning i et intersektionelt perspektiv, der søger at udvikle nye metoder til at forstå intimitet og omsorg. 


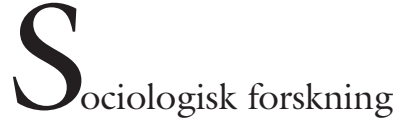
om familj och relationer har i flera decennier pekat på hur familjerelationer blir mer och mer komplexa (eller kanske till och med alltid har varit det). Trots detta har studier av och teorier om relationer ofta fortsatt att ta sin utgångspunkt i omsorgsoch intimitetsprocesser kring det heterosexuella paret och 'kärnfamiljen' (van Every 1999; Roseneil \& Budgeon 2004; Smart 2007). Kärnfamiljens starka ideologiska ställning visar sig inte minst i den kris-retorik som dyker upp med jämna mellanrum både $\mathrm{i}$ den allmänna samhällsdebatten och $\mathrm{i}$ en del sociologiskt teoretiserande, där den minskade benägenheten att ingå äktenskap liksom det ökade antalet skilsmässor tolkats i termer av ett mer självfixerat, individualistiskt och emotionellt kallare samhälle, där människor är utbytbara och omsorg - inte minst om barn - blivit en bristvara (Beck \& Beck-Gernsheim 1995; Bauman 2003). Den konservativa delen av detta kristänkande har skyllt omsorgskrisen på kvinnor. Eftersom kvinnor haft ansvar för det mesta av omsorgsarbetet om barnen, så är det enligt denna logik deras inträde på arbetsmarknaden och utträde från hemmen som orsakat omsorgsbristen. Feminister har svarat med att problematisera den förgivet tagna kopplingen mellan omsorg och kvinnlighet, liksom att peka på den problematiska exploatering av kvinnor som omsorgsarbetare som sker i familjen (se t ex Fink 2004). Vidare har feministisk och queer forskning av familjerelationer bortom 'kärnfamiljsnormen’ visat att omsorg kan ske på andra sätt, exempelvis mellan vänner (Roseneil \& Budgeon 2004; Roseneil 2004).

Inspirerad av det sistnämnda har jag frågat mig vad som händer om vi skiftar fokus från den idealiserade, men sällan realiserade 'familjen', dvs 'mamma, pappa, barn', till de faktiska nätverk av relationer människor ingår i? Och vad händer om vi dessutom låter utgångspunkten för detta studium vara barns egna berättelser om omsorg? I artikeln visar jag hur ett inkluderande av barns röster, samt en utgångspunkt i omsorgspraktiker $i$ sig snarare än i 'familjen' kan ge en komplex (och kanske även mindre krisartad) bild av barn och omsorg i Sverige idag och peka på andra sätt på vilka omsorg görs kring - och även $a v$ - barn. ${ }^{1}$

\section{OMSORG I FEMINISTISK FAMILJESOCIOLOGI}

Den marxistiska och feministiska kritiken av den inom sociologin länge rådande strukturfunktionalistiska teorins separation av arbete och hem, och förgivet tagna antaganden om omsorgen som en kvinnlig syssla i hemmet (Parsons 1965/1971; jfr Roman 2004), har enligt David Morgan (1996) varit startskottet för den feministiska familjesociologins problematisering av omsorg. Studier av och teoretiseringar kring den komplexa relationen mellan formell och informell omsorg, välfärdspolitikens ofrånkomliga betydelse för omsorgens organisering, könsarbetsdelningen och kvinnors situation inom och utanför arbetsmarknaden har alla bidragit till den kritiska förståelse av omsorg som finns inom sociologin idag (se t ex Fink 2004; Fink \& Lundqvist 2009).

Ett av de viktigaste bidragen i denna forskning har varit påvisandet av att omsorg innebär arbete. I Janet Finch och Dulcie Groves (1983) klassiska antologi The Labour of Love: Women, Work and Caring argumenterades exempelvis för vikten av att skilja på det att 'känna omsorg för' (care about) från det att 'ta hand om' i mer praktisk bemärkelse (care for). Hilary Graham argumenterade $\mathrm{i}$ antologin för att denna distinktion är viktig ur ett genusperspektiv, eftersom 'care for' konventionellt tolkats som en naturlig extension av 'care about' i föreställningar om att omsorg och omhändertagande är något kvinnor 'bara gör' som en följd av deras psyke (Graham 1991). Ge- 
nom att göra en analytisk distinktion mellan omsorg som arbete och omsorg som künsla har den feministiska forskningen kunnat lyfta fram det obetalda informella arbete som kvinnor utför i hemmet och familjen (jfr Oakley 1985; Anving 2012). Vidare har man visat på omsorgsrelationernas olika karaktär och koppling till makt, exempelvis i Waerness (1984: 211) distinktion mellan omsorg om individer som är i en beroendeställning till omsorgsgivaren, omsorg om överordnade i förhållande till omsorgsgivaren samt omsorg i symmetriska relationer. Omsorg om barn har ofta fătt tjäna som sinnebild för det förstnämnda, där vuxna (kvinnor/mödrar) framställs som de aktiva, de som 'gör' omsorgen, och barn som de beroende och passiva som tar emot (Fink 2004).

Ett problem i både 'care for'/'care about' dikotomin och teorier om omsorgsrelationer och makt är att de alltför ensidigt leder in fokus på de som ger omsorg - i feministiska studier i de flesta fall antaget vara kvinnor - och därmed inte fångar omsorgens reciproka och relationella karaktär (Brannen \& Heptinstall 2003). Jennifer Mason (1996) menar vidare, att även om uppdelningen i emotioner och arbete hade en viktig funktion i sin historiska kontext, så är den också begränsande. Mason föreslår istället att vi ska förstå omsorg som en 'sentient activity' - 'kännande aktivitet'. Detta innebär för det första att se omsorgen som specifik, förhandlad och relationell, i kontrast till på förhand given exempelvis som en konsekvens av en social kategori (som kvinna) eller genealogi (moder). Strukturella förhållanden spelar visst roll för vilka omsorgsrelationer som utvecklas, menar Mason, men de är på inget sätt entydiga eller determinerande. Vidare är omsorg som en kännande aktivitet ett åtagande som rymmer en mängd olika aktiviteter, som fysisk omsorg, stöd och hjälp, men också moraliska aspekter i relation till andra. Slutligen betonar Mason vikten av kännandet och tänkandet som aktiviteter, och den re- lationella process i vilken dessa utvecklas (Mason 1996: 25-26).

Masons begrepp öppnar upp för en mer komplex förståelse av omsorg där vi inte på förhand är låsta vid en kategoriserande ram för hur vi ska förstå eller fănga omsorgen. Samtidigt görs omsorg alltid i en social och kulturell kontext - vi kan inte fritt välja vem vi vill 'känna aktivt för'. I fallet med barn är detta tydligt. Barnet begränsas av vilka omsorgsrelationer som möjliggörs av vuxna runt omkring dem. Likaså kan barnen vara influerade av dominerande moraliska diskurser om vem som 'bör' ge omsorg och hur denna omsorg ska se ut ( $t$ ex kvinnors ansvar för praktiskt omsorgsarbete eller föreställningar om hur bra omsorg om barn ser ut). Samtidigt ser barnen inte heller nödvändigtvis all typ av omsorgspraktik som ges till dem som 'kännande aktivitet'.

Sammanfattningsvis kan vi konstatera att de viktigaste bidragen från de feministiska och familjesociologiska teoretiseringarna kring omsorg har varit avmystifierandet av omsorgsbegreppet och förståelsen av omsorg som ett arbete, identifikationen av makt som en central dimension - omsorg görs och får olika karaktär beroende på de inblandade personernas sociala position liksom argumenterandet för omsorgens relationella karaktär och det komplexa känslomässiga 'görande' som omsorg är. Detta ger en ram för att öppna upp begreppet omsorg, som är särskilt behjälplig i forskning om barn och omsorg. Barn är på grund av den strukturella position de $\mathrm{i}$ de flesta sammanhang tilldelas i dagens samhälle - ofta i en beroende- och underordnad ställning i förhållande till exempelvis vuxna omsorgsgivare, men kan samtidigt ses som mer än passiva mottagare av omsorg och vara en aktiv part i det relationella görandet av omsorg, dels i den omsorg som uppfattas som en aktivitet utförd av andra, men också som aktiva görare av omsorg själva. 


\section{OMSORG FRÅN ETT BARNPERSPEKTIV}

Synen på barn har förändrats markant i samhället de senaste decennierna genom den framväxande barnrättighetsdiskursen, och så även inom forskning, framförallt i det som kommit att kallas 'New Sociology of Childhood' (Brannen 1999; Näsman et al. 2008; Christensen \& James 2008). Där tidigare forskning framförallt sett barn som passiva och (i bästa fall) intressanta som 'blivande vuxna', ser den nya barndomssociologin barn som subjekt i sig och som aktiva medkonstruktörer av sin barndom och sin vardagsvärld (Halldén 2003). Detta gäller inte minst omsorgspraktiker i familjen, där barn i allra högsta grad är inblandade i och påverkade av de relationer som skapas (Brannen et al 2000).

Denna insikt speglar också en del av den internationella forskningen kring barn och omsorg, som gått från ett singulärt fokus på vuxna - framförallt föräldrar - till att också försöka inkludera barns röster. Julia Brannen, Kalwant Bhopal och Ellen Heptinstalls (2000; samt Brannen \& Heptinstall 2003 ) studie i Storbritannien i slutet av 90talet visar hur ett inkluderande av barns röster kan ge en mer komplex bild av omsorg, inte minst vad gäller barns faktiska görande av omsorg - praktisk och emotionell - i vardagen, liksom barns förmåga att aktivt förhandla och resonera kring omsorgsrelationer i sin vardag (jfr även Mason \& Tipper 2008). Ett intressant fynd i Brannen et als studie var att de, trots valet att i forskningsdesignen fokusera på barns förståelse av sig själva i relation till sina föräldrar, fick en mängd berättelser om 'andra' som omsorgsgivare, det vill säga relationer utanför barn-förälder-relationen (Brannen \& Heptinstall 2003: 194).

Detta korresponderar väl med det som framträder i min egen studie. Frågan för denna studie, med titeln 'Relationer kring omsorg bortom "familjen" (Eldén FAS 2010-0505) var, vad som händer om vi studerar omsorg utifrån barns perspektiv. Som titeln signalerar, fanns ett antagande om att studien skulle kunna öppna för att andra omsorgsrelationer än de förgivet tagna - i första hand föräldraomsorgen - skulle kunna framträda. ${ }^{2}$ För att nå dithän blev det dock nödvändigt att inte bara ha en öppen forskningsfråga utan även öppna metodverktyg. Ambitionen att inte från början anta att föräldrarelationen eller kärnfamiljen var den viktigaste omsorgspunkten i barnets vardag, gjorde att jag ville undvika att introducera begreppet 'familj' på ett för tidigt stadium i mötet med barnen. Likaså var ambitionen att inte på förhand definiera för barnet vad omsorg är eller var den äger rum, exempelvis genom att bara fråga om vem som utför praktiska sysslor i hemmet, utan istället öppna för att barnets egen reflektion kring vardagens praktiker, emotioner och relationer.

Det sätt som jag kom att arbeta på i denna studie var genom en kombination av två teckningsmetoder (jfr Thomson, 2008; Gabb 2010; Eldén 2013a; Fernqvist 2010). Den första metoden som inleder intervjun med barnen kallar jag 'rita-din-dag'. Barnet får ett papper med fyra rutor och ombeds måla sin dag; i första rutan något som händer på morgonen, i andra under dagen, i tredje på eftermiddagen och i fjärde på kvällen. Under tiden som barnet målar samtalar jag och barnet om vad som händer på bilden, vilka som finns där tillsammans med barnet, vad de gör etc.

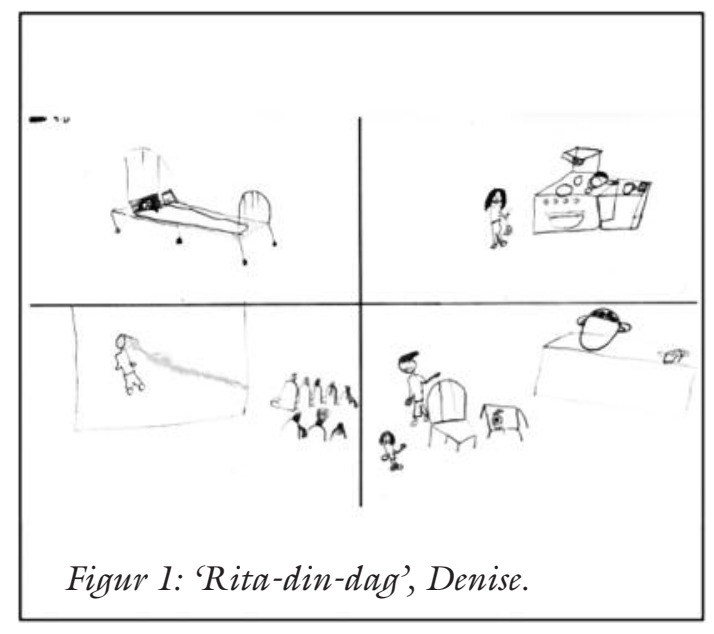


Tanken med metoden är att låta förgivet tagna skeenden, som t ex ätandet av frukosten eller promenaden till skolan få vikt genom själva ritandet. Ritandet blir en utgångspunkt och en slags plattform utifrån vilken jag och barnet kan samtala. Likaså rymmer metoden en rörelse - barnets rörelse under dagen - som möjliggör ett făngande av omsorg som görs på andra platser än hemmet. Denise tredje bild ovan visar exempelvis henne själv när hon är på bio tillsammans med sin moster, en relation som visade sig viktig för Denise.

Den andra metoden utgörs av den inom familjeforskningen mer vanligt förekommande metoden koncentriska cirklar (se t ex Spencer \& Pahl 2006, Mason \& Tipper 2008; Smart et al., 2001). Jag använder den på så sätt att barnet ombeds rita sig själv i mitten och de som 'tar hand om dig' och de som 'är viktiga' för dig runt omkring.

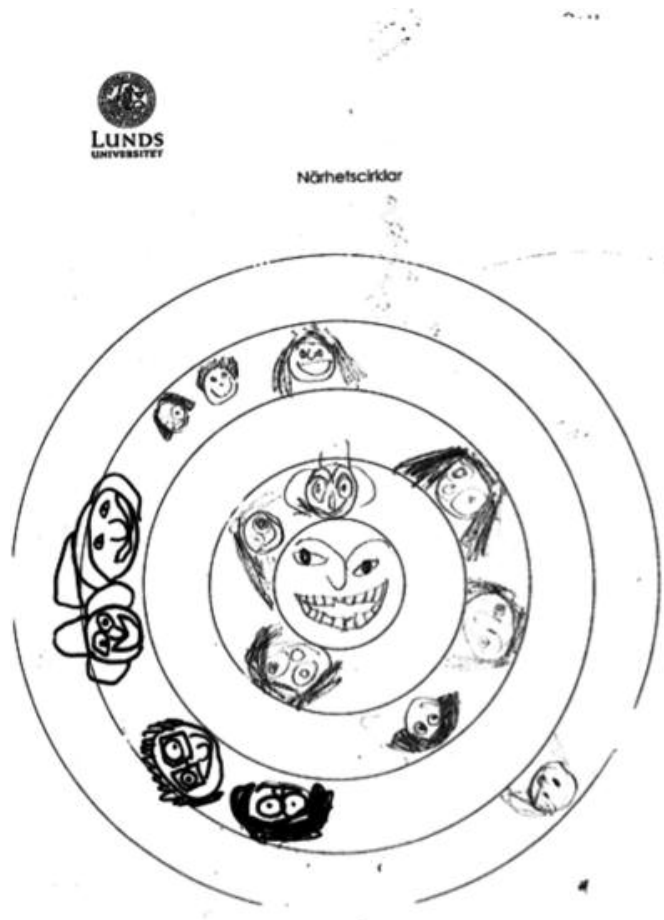

Figur 2: Närhetscirkel, Hilde.
Om 'rita-din-dag' tog sin utgångspunkt i omsorgsgörandet i vardagen tar närhetscirklarna sin utgångspunkt i omsorgens relationer. På så sätt ger metoderna i sig tyngd åt olika dimensioner av omsorgsbegreppet. Att jag i närhetscirkelritandet frågar efter både 'tar hand om' och 'är viktiga' är medvetet, då det ger barnet en möjlighet att själv bestämma, och också reflektera kring, vad omsorg är. Denna metod fångar också omsorgsgivare som kanske inte finns i vardagen men som gör omsorg ändå. Tillsammans ger metoderna en komplex bild av omsorg och tillåter därmed barnen att vara subjekt; kompetenta att se, berätta om och reflektera kring sin vardag och sina relationer (se Eldén 2013a för en mer utförlig diskussion).

I projektet har 23 barn mellan 5 och 12 år intervjuats. Barnen kommer från olika familjeförhållanden (kärnfamilj, ensamstående, regnbågsfamilj, ombildad familj) och har olika socioekonomisk och etnisk bakgrund. Urvalet har framförallt gjorts med snöbollsmetoden. ${ }^{3}$

\section{OMSORGENS VARDAGLIGA KOMPLEXITET: \\ VEM TAR HAND OM BARNEN?}

Denise, vars 'rita-din-dag' teckning vi såg ovan (figur 1), är 9 år och bor med sin mamma, pappa och sin äldre halvsyster Molly. Denises morgonteckning visar henne själv i sängen när hon är sjuk, vilket leder oss in på att prata om hur det brukar vara när hon är sjuk.

Denise: $[\ldots]$ om min mamma inte har tid så kanske jag ringer till min mormor, så då kanske hon kommer, för jag vill helst inte att, alltså det finns sån här hostmedicin, och jag vill inte hälla upp det själv om jag tar för mycket.

Sara: Nej det är ju bra.

Denise: Och då så brukar jag ringa henne, och så kanske hon kommer och så kanske vi ser på en film eller pysslar vi kanske lite, eller 
om jag sover sen så går hon hem och sen när jag vaknar kan jag ringa henne och...[...] Om Molly [syster] är hemma så är vi ju tillsammans och ser på film och så, fast om hon inte är hemma, om jag är ensam, då kanske jag ringer Maria [moster] eller nån annan moster eller så.

Hela Denise berättelse är full av andra omsorgsgivare än hennes mamma och pappa. Hennes mormor, mostrar, halvsyskon, morbröder, farbröder och kusiner dyker hela tiden upp i hennes berättelse om vardagen. Släkten är viktig för Denise, men där finns även grannar som gör omsorg, liksom även hennes halvsysters mamma, Agneta.

Denise: Att man är så här många tycker jag är bra, att man kanske, om man är sjuk till exempel och det är ingen hemma, då finns det alltid nån man kan ringa eller så, eller... eller som Agneta, när jag blir sugen på att kanske odla, så ger hon mig så här små paprikor och så här lösa frön, det finns där borta.

Denises närhetscirklar visar också hur hon upplever sig omgiven av människor som tar hand om henne och som är viktiga för henne - hon ritar in 17 personer i cirkeln närmast henne själv, fyra i nästa cirkel och en i den yttre cirkeln.

Alla barns berättelser är inte lika fulla av 'andra' omsorgsgivare som Denises, men utan undantag så finns i barnens berättelser en närvaro av andra än genetiska föräldrar som ger omsorg - praktisk och emotionell - i vardagen. De 'andra' som dyker upp i barnens berättelser är exempelvis styvföräldrar, mor- och farföräldrar, syskon och halvsyskon, andra barn, andra släktingar, gudföräldrar, grannar, vänner till föräldrar, skol- och dagispersonal, aktivitetsledare ( $\mathrm{t}$ ex fotbollstränare), föräldrars ex-partners, kompisars föräldrar, barnvakter och halvsyskons föräldrar. Att 'andra' utför omsorg betyder dock inte att genetiska föräldrar är oviktiga. I familjer där båda föräldrar bor med eller har nära kontakt med barnet ( $\mathrm{ex}$ genom växelvis boende) så är båda föräldrar också involverade i omsorgen om barnet enligt samtliga av de intervjuade barnens berättelser.

Den bild av omsorgen i vardagen som framträder i barnens berättelser kan, vill jag hävda, betecknas som en 'omsorgens vardagliga komplexitet'. Uttrycket relaterar till Jennifer Masons och Becky Tippers (2008) karaktärisering av barns görande av släktskap, som de karaktäriserar som en 'ordinary complexity of kinship'. Barn i alla typer av familjekonstellationer konstruerar enligt Mason och Tipper släktskapsband på ett kreativt och aktivt sätt (inte bara barn i 'icke-normativa' familjebildningar som påvisats $\mathrm{i}$ annan forskning, se $\mathrm{t}$ ex Smart et al 2001). På ett liknande sätt kan man i min studie se hur barnen oberoende av familjekonstellation berättar om och aktivt förhåller sig till omsorg på så sätt att omsorgens praktiker och relationer framträder som komplexa, det vill säga överskridande normen om kärnfamiljsomsorg.

I Denises berättelse dominerar omsorgsgivare som hon på något sätt är släkt med. Också i andra barns berättelser är släktingar viktiga, framförallt när det gäller vuxna omsorgsgivare, men inte på något sätt uteslutande så. Grannomsorgen framstår exempelvis som mycket viktig för flera av barnen. Nilla som är 7 år och bor med tre syskon, mamma och pappa väver under hela intervjun in grannar - barn och vuxna - i sin berättelse. Hon tar mig med till sitt fönster och pekar ut var de bor och berättar vilka hon känner och vad hon gör med dem. För Gabriella som är 10 år och bor tillsammans med sin pappa är grannarna också mycket viktiga. Gabriella och hennes pappa bor sedan en tid tillbaka i ett kollektivhus med flera gemensamma aktivitetslokaler och även möjlighet att laga och äta mat tillsammans några gånger i veckan. Hon berättar om skillnaden mellan hur de har det nu och hur det var tidigare då de bodde i ett vanligt bostadsområde där kontakten med grannarna var mycket mindre. $\mathrm{Nu}$ känner 
hon många, både yngre och äldre, och hon 'hänger' ofta nere i de gemensamma lokalerna tillsammans med sina kompisar. När vi i slutet av intervjun diskuterar begreppet 'familj' föreslår Gabriella till och med att man skulle kunna kalla alla i kollektivhuset för en familj.

En annan viktig aktör som dyker upp i flera av barnens berättelser är gudföräldrar. För Åsa (8 år) som bor med sina två mammor och lillebror, är både hennes egna och hennes lillebrors gudföräldrar mycket viktiga. Gudföräldrarna är ofta barnvakt, och särskilt en gudmor är mycket närvarande $\mathrm{i}$ vardagen då hon är en av mammornas bästa vän. Åsa ritar sina gudmödrar i närhetscirkeln direkt utanför den där hon ritat sina mammor och sin bror, i samma cirkel som hennes mormor och morfar, som hon också säger sig vara mycket nära. I Sallys (6 år) berättelse är gudföräldrarna också grannarna, vilket hon tycker är bra. Hon har också en klar bild av vad deras roll är:

Sara: Finns det någon som... av grannarna som brukar ta hand om dig?

Sally: Jo men alltså grannen är... var med på mitt dop och så typ om mamma inte typ tar hand om mig ordentligt så typ... [...] Eller pappa, alltså att jag inte trivs bra, så är grannen typ... Då så... grannen typ tar hand om mig om jag inte mår bra i mitt... i mitt hus.

Karaktären på 'andras' involvering i omsorgen kring barnen skiftar dock mellan barnens berättelser och här kan vi skönja skillnader mellan olika familjeformer. 'Andras' närvaro i Denises berättelse ovan gör det möjligt för hennes båda föräldrar att fortsätta sina respektive karriärer och framstod som mindre akut nödvändig (om än inte mindre viktig för Denise!) än 'andras' närvaro i Cillas berättelse. Cilla, som är 7 år och bor tillsammans med sin mamma, har andra som tar hand om henne i princip varje dag för att få vardagen att gå ihop praktiskt och ekonomiskt. För att klara att försörja familjen behöver mamman arbeta heltid och fritids öppettider räcker inte till. På familjens kylskåp hänger ett schema över hur Cillas omsorg organiseras. Cilla sover ofta över hos sin mammas ex-partner eller hos kompisar, går hem till kompisar efter skolan, och tas om hand av mammans expartners föräldrar och sin egen mormor. Detta speglar sannolikt den utsatta position som enförsörjarfamiljer har i dagens Sverige, där 'omsorgspusslet' försvårats ytterligare av försämrade socialförsäkringar (Lundqvist 2013). Cillas och hennes mammas situation är ansträngd, men det betyder för den skull inte att den omsorg Cilla får av 'andra' uppfattas som negativ av henne tvärtom framstår den som lika positiv som i Denises berättelse.

Samtidigt är det inte givet att omsorgssysslor som utförs av 'andra' nödvändigtvis uppfattas som omsorg av barnen, eller att denna omsorg leder till att en viktig relation skapas. Av betydelse här är de vuxnas inställning till andras omsorgsgörande; i vilken grad föräldrarna bjuder in till och uppmuntrar att en nära relation skapas mellan barnet och den andra, och i vilken grad den andra är intresserad av att skapa en djupare relation. I både Gabriellas, Denises och Cillas berättelser är det exempelvis tydligt att föräldrarna uppmuntrar och bjuder in andra till att ha en nära relation med barnen. Andra, till exempel Rebecka (12år) som har få 'andra' runt omkring sig, verkar begränsas av föräldrarnas relationer, exempelvis genom ett antal konflikter med släkten som Rebecka berättar om och som kommit i vägen för hennes relation till mor- och farföräldrarna. Det är dock inte bara de vuxnas inställning som är avgörande. Barnen är själva aktiva $i$ att både initiera men också $i$ att välja bort omsorgsrelationer. Milo ( 7 år) är ett exempel på det. I hans berättelse om vardagen finns flera personer som gör praktiska omsorgssysslor i vardagen, men dessa personer inkluderas inte $\mathrm{i}$ närhetscirklarna och framstår inte som så viktiga för Milo (se också Eldén 2013a). I Jasmines ( 9 år) berättelse finns på 
ett liknande sätt ett avståndstagande från 'mammas kompisar' som visserligen är mycket delaktiga i Jasmines vardag, men som hon inte vill se som nära eller viktiga, $\mathrm{i}$ kontrast till hennes mormor (som diskuteras mer nedan). Detta visar barnens aktiva 'reckoning' (Mason \& Tipper 2008) i omsorgsgörandet. Barnen är involverade i ett komplext förhandlande - inkluderande och exkluderande - kring vem som får vara nära och ses som viktig. Detta blir avgörande för om en djupare omsorgsrelation skapas.

\section{DET FORTSATT KVINNLIGA OMSORGSARBETET}

Med tanke på de ständiga rapporterna om fortsatt ojämlik omsorgs- och hushållsarbetsdelning också i det jämlika Sverige (se $\mathrm{t}$ ex Ahlberg et al. 2008; Grönlund \& Halleröd 2008; Anving 2012) så är det kanske inte särskilt förvånande att barnens berättelser vittnar om en fortsatt reproduktion av omsorg som en i första hand kvinnlig aktivitet, om än inte nödvändigtvis en aktivitet förbehållen mödrar. Som påpekades ovan ser barnen visserligen både mammas och pappas deltagande i omsorgen som självklart i de heterofamiljer där barnet bor med båda föräldrar, samt även i de fall där barnen bor växelvis hos båda föräldrar. Explicita frågor om vem som lagar mat, vem som diskar, vem som städar etc. besvaras påfallande ofta med "mamma och pappa". Samtidigt framkommer ofta indirekt i berättelserna en bild av att mamma gör mer än pappa. Emil ( 5 år) som bor tillsammans med sin mamma, pappa och lillebror, svarar ofta 'mamma och pappa' när jag frågar explicit om vardagens praktiker. När han tänker efter lite nyanserar han dock sitt svar.

Sara: ...hur brukar det vara här hemma, vem brukar laga maten?

Emil: Mamma eller pappa. Pappa gör minst, han lagar bara lite mat. Bara på tisdag och torsdag. Och mamma lagar mat ofta annars. Mamma lagar mat mest.
Det är också mamma som dyker upp mest i Emils berättelse om vardagen när han gör 'rita-din-dag'. Mamma hämtar oftast på dagis, tar hand om tvätten och gör frukost (jfr Samuelsson 2008). Samtidigt finns i ett par av berättelserna från barn i heteroparfamiljer ingen diskrepans mellan tal om att mamma och pappa gör allt tillsammans och beskrivningen av vardagen. Den könade föräldraomsorgen verkar alltså ha utmanats i några av de heterofamiljer jag fått berättelser från, från barnens perspektiv.

Vad gäller omsorg från 'andra' finns också här en genusaspekt. De andra - i alla fall andra vuxna - som dyker upp i barnens berättelser är oftast kvinnor. Denises tal ovan om vad som händer när hon är sjuk är tydligt - de andra som är involverade i omsorgen om henne är nästan uteslutande kvinnor. Katja ( 7 år) säger till en början att hon känner alla sina kompisars föräldrar, men tänker sedan efter och ändrar sig, 'jag känner inte allas killar', de hon känner är mammorna. På Emils närhetskarta har mormor en självklar plats. Först efter en stund, och efter att han ritat in flera andra, kommer han på att han ska rita in morfar.

Emil: [tittar på de han ritat på kartan] Mormor, men utan morfar! [...] Och nu ska jag rita morfar.

Sara: Vad gör du med morfar då?

Emil: Ehm...han bara, han är inte med mig, och jag är inte med han.

Sara: Jaså.

Emil: Han bara läser tidning och tittar på TV.

Just mor- och farmödrar framstår som speciellt viktiga i barnens berättelser. Detta korrelerar väl med kvantitativ forskning som visat att mor- och farföräldrars betydelse för sina vuxna barns familjer har ökat generellt i Sverige, men att mor- och farmödrar är särskilt viktiga vad gäller den praktiska omsorgen (Björnberg \& Ekbrand 2008; Halleröd 2008). Särskilt viktig verkar mormödrars roll vara för barn till ensamlevande mammor, och även på ett liknande 
sätt vad gäller farmor i den enda ensammapappa-familjen i studien (jfr Roman 2013). Som redan nämnts är mormor en av flera viktiga aktörer som får Cillas omsorgsvardag att gå runt. För Jasmine som bor med sin mamma är mormor helt avgörande $\mathrm{i}$ vardagen. Jasmine bor över hos mormor flera gånger i veckan. Jasmine jämför sin vardag hos mormor och hos mamma och det framstår som att hon i alla fall i vissa avseenden trivs bättre hos mormor, eftersom mamma "är upptagen med datorn hela tiden" medan mormor har tid att spela spel och förhöra henne på läsläxan. Mormor hjälper även Jasmine och hennes mamma med vardagsbestyren och kommer ofta med mat och kakor eftersom mamma inte tycker om att laga mat enligt Jasmine. Själv tycker hon mycket om att hjälpa mormor med matbestyren, särskilt kakbaket.

Omsorgsgörandets fortsatta utförande av framförallt kvinnor pekar, menar jag, på vikten av att också fortsätta tala om omsorg i termer av arbete. Kvinnors omsorgsarbete är ett fysiskt och psykiskt åtagande som visserligen kan upplevas som mycket meningsfullt och givande, men som samtidigt är krävande och - ibland - begränsande. Att det i högre grad är 'andra' kvinnor än mammor som gör det, kanske framförallt den äldre generationen i form av mor- och farmödrar, men också i högre grad anställda omsorgsarbetare - fyra av de deltagande barnen berättar att familjen anställer städerskor - förändrar omsorgsarbetets karaktär och relationer och kan också potentiellt innebära att nya former av ojämlikheter skapas.

\section{BARN SOM OMSORGSGÖRARE}

Denises andra 'rita-din-dag'-bild ovan visar henne själv i färd med att göra varm choklad till sin storasyster. I barnens berättelser dyker omsorgsgörande utfört av barn ofta upp; det omsorgsgörande de själva gör gentemot andra barn eller gentemot vuxna - liksom det omsorgsgörande de menar att andra barn gör för dem. Omsorgen kan ha karaktären av utförande av praktiska sysslor - som i syskonparet Axel och Adrians (9 och 10 år) tal om hur de lagar mat åt varandra, eller Åsas berättelse om hur hon hjälper till med att hämta sin lillebror på dagis - men är minst lika ofta ett emotionellt görande. Milo insisterar exempelvis på att hans lillebror William - som bara är ettoch-ett-halvt år - är den 'viktigaste' för Milo, och även tar hand om honom, exempelvis genom att 'natta honom' (de sover i samma säng) vilket är väldigt viktigt för Milo eftersom han är så mörkrädd.

Barnens berättelser om omsorg barn emellan handlar inte bara om syskonomsorg. För Cilla var exempelvis en av hennes jämnåriga bästa vänner det viktigaste emotionella stödet i den krissituation som uppstod i familjen för några år sedan. Gabriella i sin tur ritar in den vuxna Jenny - hennes pappas ex, och också hennes granne - i sina närhetscirklar och berättar att hon ofta är hemma hos Jenny och också gärna pratar med henne om saker som är jobbiga, men också hennes jämnåriga kompis Matilda har en självklar plats i cirklarna.

Sara: ...Jenny är den som du brukar prata med om du behöver prata?

Gabriella: Ja.

Sara: Är det nån mer?

Gabriella: Matilda kan också vara bra. Emma [en annan kompis] är mest busig [skrattar], hon tar inte allt på allvar, hon tror att det är bus ibland så då blir inget roligt längre, men Matilda hon chattar jag med datorn och så om det är nått som har hänt i skolan och så. ...

Sara: Tycker du att dom vuxna och de kompisar som du har runt omkring, brukar dom ha tid att prata när du vill prata då?

Gabriella: Ja. Det är synd om Matilda för pappan där jobbar i kiosken hela dagarna och hon, "kan vi göra nått”, nej, det är synd om henne för när hon säger "kan vi göra nått", "nej jag kan inte nu".

Sara: För han måste jobba hela tiden? 
Gabriella: Ja det är jättejobbigt, synd om henne, hon bara “jag vill inte ha det så här”, man bara stackars henne... och bara kom till mig liksom.

Sara: Ja brukar hon göra det då?

Gabriella: Ja, jag brukar ringa till henne och sen, jag har deras telefonnummer...

I sin berättelse gör inte Gabriella någon skillnad mellan Jenny som vuxen och Matilda som barn; båda är bra att prata med och finns där för henne när hon behöver dem. Dessutom finns en tydlig reciprocitet i relationen mellan Matilda och Gabriella, de finns där för varandra. Gabriella ser och värderar högt den viktiga roll hon har i Matildas liv. Hon kan ge omsorg där den vuxna relationen - i detta fall till pappan - inte fungerar.

Berättelserna om vänskapsomsorg är många $\mathrm{i}$ intervjuerna med barnen. Inte alla är okomplicerade eller entydiga, men det råder ingen tvekan om att barnen ser vänner som omsorgsgivare, både i praktisk och emotionell bemärkelse. Studier som fokuserat vuxna (t ex Roseneil och Budgeon 2004, samt Roseneil 2004, 2007) har visat att vänskap i vuxenrelationer mycket väl kan anta karaktären av och tolkas som omsorgsrelationer. På ett liknande sätt menar jag att barns omsorg om vänner skulle kunna ses som omsorgsrelationer, liksom även omsorg syskon och halvsyskon emellan.

Att barn gör omsorg har påvisats i andra studier, exempelvis i Gullestads klassiska studie av norska 'passepiker' (1984), samt i Solbergs (1994) och Samuelssons (2008) studier av barns praktiska omsorgsarbete i familjen. Dessa studier visar på diskrepansen som råder i samhället mellan, å ena sidan, de faktiska praktiker barn är involverade $i$, och å den andra, föreställningar om barndom som en 'bekymmersfri tid' med ideal om att barn ska vara befriade från olika typer av ansvar i förhållande till andra (se också Wyness 2006; Wihstutz 2011). Det kritiska i barns omsorgsgörande blir särskilt tydlig i de fall barn tar hand om vuxna
(Smart et al 2001; Brannen \& Heptinstall 2003; Wihstutz 2011). ${ }^{4}$ Denna typ av omsorg återfinns också i denna studie, till exempel i Åsas berättelse om hur hon tar hand om sin sjuka mormor och morfar, både genom att hjälpa med praktiska göromål men också genom att bara finnas där för dem. Åsa är stolt över det hon kan göra för sina morföräldrar, på ett liknande sätt som Gabriella i citatet ovan är stolt över hur hon tar hand om sin vän Matilda. Samtidigt finns det också berättelser om omsorgsgörande av både vuxna och andra barn som inte upplevs lika positivt. Ett av barnen uttrycker exempelvis en viss trötthet över att behöva lyssna på sin mammas ständiga prat, och väljer därför gärna själv att prata med någon annan än mamma - helst sin bästa kompis eller mormor - när hon känner sig ledsen. Sammantaget visar berättelserna i min studie att barns omsorgsgörande visst, och i vissa sammanhang, kan upplevas som en börda av barnen, men samtidigt - och framförallt - är barnen stolta över att kunna ta hand om andra, vuxna och barn (jrf Samuelsson 2008; Wihstutz 2011). Likaså värderar barnen andra barns omsorg mycket högt. Barnens egna berättelser utmanar därmed förgivet tagna föreställningar om barn som passiva mottagare av omsorg liksom av barndom som en tid utan omsorgsansvar och öppnar för en förståelse av omsorgsgörande som en vardaglig aktivitet barn ofrånkomligen är involverade i.

\section{AvsLutningsvis}

I denna artikel har jag argumenterat för vikten av att inkludera barns röster och perspektiv i forskning om omsorg, familj och nära relationer. Barn är aktörer i dessa sammanhang och som sådana är de - precis som vuxna - viktiga för forskaren att samtala med. ${ }^{5}$ Min studie visar inte att föräldrar är oviktiga i omsorgen kring sina barn. Däremot visar den att där finns en mängd 'andra' som barnen uppfattar tar hand om dem och som barnen själva tycker att de tar 
hand om. Dessa andra är ibland perifera $\mathrm{i}$ barnens liv, men ibland är de helt avgörande för deras välmående och till och med viktigare än en förälder. Dessa 'andra' finns vidare $\mathrm{i}$ barnens liv oberoende av vilken familjeform de lever i, även om de kan ha olika roller och olika betydelse för olika aspekter av barnets vardag. Jag har också visat att även omsorg utförd av 'andra' reproducerar könade mönster, vilket pekar mot vikten av en fortsatt kritisk feministisk diskussion kring omsorgsarbetets ojämlika karaktär och konsekvenser. Framsteg mot jämlikare heteroparrelationer kanske har gjorts vad gäller omsorg om barn, men vad betyder det att andra kvinnor - som exempelvis mor- och farmödrar - går in och tar över en del av omsorgsansvaret? Den bild barnen ger av mor- och farmodersomsorgen är nästan utan undantag positiv, men forskning saknas kring hur mor- och farmödrar själva upplever detta.

Vidare har jag velat lyfta frågan hur vi ska förstå barns eget omsorgsgörande. Barnen ser helt klart sig själva som görare av omsorg - ofta med stolthet - och ser också andra barn som görare av omsorg i sina egna liv. Att hävda barns 'omsorgskompetens' är dock på inget sätt oproblematiskt. Som Sandin (2012) påpekar finns i idag en spänning mellan att se barn som 'kompetenta' (ett synsätt sprunget ur barnrättighetsdiskursen) och samtidigt i behov av skydd och 'rätt' omsorg och uppfostran. Wihstutz (2011) menar vidare att det kan vara vanskligt att hävda barns omsorgskompetens i en tid när välfärdens institutioner monteras ner och ersätts av ett (nygammalt) fokus på familjeomsorg. 6 Samtidigt fokuseras och framställs barns omsorgsgörande i denna debatt ofta som en 'filling-in-the-gaps'-aktivitet: barn som gör omsorg antas göra det för att vuxna av någon anledning inte gör det (Wihstutz 2011: 449). ${ }^{7}$ Vad som framkommit i min studie är dock inte $\mathrm{i}$ första hand omsorg som görs av barn i sammanhang där vuxenomsorgen på något sätt 'fallerar'. Istället handlar det om omsorg som en integrerad och självklar del av barnens vardag. Detta 'görande' kunde framträda i studien tack vare den metodologiska utgångspunkten, som öppnade för en komplex förståelse av omsorg, inte minst genom det aktiva valet att inte ta utgångspunkt i 'familjen' i intervjuerna. Därmed blev det möjligt att frångå förutbestämda kategorier och se omsorg som förhandlat och specifikt och upptäcka den omsorg som görs 'bortom' kategorier och utanför kärnfamiljsnormerna - för barn och av barn. På så sätt kan vi upptäcka nya sätt på vilka omsorg görs - sätt som både innebär ett positivt skapande av relationer, men som också kan innebära nya former av ojämlikhet. Kärnfamiljens eventuella sammanbrott innebär inte den omsorgskris som dystoperna förutspår, men leder sannolikt inte heller till en framtid på rosa moln, där omsorgsarbete delas jämlikt och solidariskt. Vad som dock för framtiden är nödvändigt, är att se och erkänna den mångfald av omsorgsrelationer som faktiskt finns kring och görs av barn.

\section{NOTER}

1. Artikeln baseras på forskning finansierad av FAS (Eldén FAS 2010-0505). Stort tack till tidskriftens anonyma referees, redaktörerna samt Terese Anving för konstruktiva kommentarer i textens olika faser.

2. Detta antagande gjordes på grundval av andra studier om omsorg, där avsteg gjorts från den förväntade normen, exempelvis i studier av ensamstående föräldrars (Gilles 2007; Fink \& Holden 2009), 'singlars' (Roseneil \& Budgeon 2004; Budgeon 2008) och homosexuella familjers omsorgsrelationer (Weston 1991; Weeks et al. 2001). Även studier av barn i 'icke-normativa' familjekonstellationer, så som barn med skilda föräldrar (Smart et al 2001) har visat på förekomsten av omsorgsrelationer utanför föräldra-barn relationen.

3. I studien deltog 15 tjejer och åtta killar, 14 av dem levde med båda sina genetiska föräldrar, två levde i regnbågsfamiljer, tre i ombildade familjer och växelvis boende, fyra levde med ensamstående föräldrar. Fem av barnen hade föräldrar som inte 
var födda i Sverige. Föräldrarna hade en rad olika yrken, från enklare servicearbeten till högre chefer. Intervjuerna spelades in i sin helhet och hade mycket varierande längd, från 15 minuter till två timmar. Alla intervjuer utom en utfördes i barnens hem. Kontakt med barnen togs via föräldrarna, både barn och föräldrar lämnade samtycke till barnens deltagande. Snöbollsmetoden som teknik samt etiska frågor i projektet diskuteras utförligt i Eldén (2013b). Studien är etikprövad (EPN Lund 2010-577).

4. Se även 'children-as-carers' forskningen som framförallt fokuserat de negativa aspekterna av barn som omsorgsgörare i familjer där någon av föräldrarna inte kan utföra de praktiska omsorgssysslorna, se t ex Aldridge (2008) och för en kritisk diskussion av denna forskning, Wihstutz (2011). 5. Barn är dock inte någon homogen grupp vars 'autentiska röster' vi kan fånga, och givet den socialt underordnade position barn har i samhället är det av största vikt att forskning som säger sig utgå från 'barns röster' hanterar representationsproblematiken med största försiktighet (Halldén 2003; Komulainen 2007; Eldén 2013a).

6. Se också Halldén 2003 samt Lindgren \& Halldén 2001 för en diskussion om det problematiska med att ett hävdande av 'barns perspektiv' blir en intäkt för politiska förändringar.

7. Som Wihstutz påpekar har 'children-as-carer' studier denna utgångspunkt, vilket också reproducerar en syn på omsorg "framed by middle-class oriented concepts of family" (Wihstutz 2011: $452)$.

\section{LITTERATUR}

- Ahlberg, Jessica; Roman, Christine \& Duncan, Simon (2008): Actualizing the 'Democratic Family'? Swedish Policy Rhetoric versus Family Practices, i: Social Politics: International Studies in Gender, State and Society, 2008/1

- Aldridge, Jo (2008): All work and no play? Understanding the needs of children with caring responsibilites, i: Children and Society, 2008/4 - Anving, Terese (2012): Måltidens paradoxer. Om klass och kön i vardagens familjepraktiker. Lunds universitet, Lund

- Bauman, Zygmunt (2003): Liquid love. On the Frailty of Human Bonds. Polity Press, Cambridge.

- Beck, Ulrich \& Beck-Gernsheim, Elisabeth (1995): The normal chaos of love. Polity Press, London
· Björnberg, Ulla \& Ekbrand, Hans (2008): Intergenerational solidarity and social structures in Sweden: class, ethnicity and gender in public and private support patterns, i: Saracceno, C (ed.): Families, Ageing and Social Policy: Generational Solidarity in European Welfare States. Edgar Elgar, London

- Brannen Julia (1999): Reconsidering Children and Childhood: Sociological and Policy Perspectives, i: Silva, Elisabet \& Smart, Carol (ed.): The New Family? Sage: London

- Brannen, Julia; Heptinstall, Ellen \& Bhopal Kalwant (2000): Connecting children: Care and family life in later childhood. Routledge, London - Brannen, Julia \& Heptinstall, Ellen (2003): Concepts of care and children's contribution to family life, i: Brannen, Julia \& Moss, Peter (eds.): Rethinking children's care. Open University Press, Buckingham

- Budgeon, Shelley (2008): Couple Culture and the Production of Singleness, i: Sexualities, $2008 / 3$

. Christensen, Pia \& James, Allison (2008): Introduction: Researching children and childhood cultures of communication, i: Christensen, Pia \& James, Allison (eds.): Research with Children: Perspectives and Practices. Falmer Press, London - Eldén, Sara (2013a): Inviting the messy: Drawing methods and 'children's voices', i: Childhood, 2013/1

- Eldén, Sara (2013b): 'You child is just wonderful!': On ethics and access in research with children. Journal of Comparative Social Work, 2013/2 . Fernqvist, Stina (2010): (Inter)Active Interviewing in Childhood Research: On Children's Identity Work in Interviews, i: The Qualitative Report, $2010 / 6$

- Finch, Janet \& Groves, Dulcie (red) (1983): The Labour of Love: Women Work and Caring. Routhledge, London

· Fink, Janet \& Lundqvist, Åsa (2009): Välfärd, genus och familj. Liber, Malmö

- Fink, Janet (ed.) (2004): Care. Personal Lives and Social Policy. The Open University, Milton Keynes

. Fink, Janet \& Holden, Katherine (2009): Familjeansvar bland ensamstående, i: Lundqvist, Åsa \& Fink Janet (red.): Välfärd, genus och familj. Liber, Malmö

- Gabb, Jacqui (2010): Researching intimacy in families. Palgrave Macmillan, Basingstoke - Gilles, Val (2007): Marginalized Mothers: Exploring working-class experiences of parenting. Routledge, London 
. Graham, Hilary (1991): The Concept of Caring in Feminist Research: The Case of Domestic Service, i: Sociology, 1991/1

. Grönlund, Anne \& Halleröd, Björn (2008): Den vackra visionen och den vrånga vardagen, i: Grönlund, Ann \& Halleröd, Björn (red.): Jämställdhetens pris. Boréa, Umeå

- Gullestad, Marianne (1984): Kitchen-table society: a case study of the family life and friendships of young working-class mothers in urban Norway. Universitetsforlaget, Oslo

- Halldén, Gunilla (2003): Barnperspektiv som ideologiskt eller metodologiskt begrepp, i: Pedagogisk forskning i Sverige, 2003/1-2

· Halleröd, Björn (2008): Flergenerationsfamiljen. Att hjälpa och bli hjälpt, i: Grönlund, Ann \& Halleröd, Björn (red.): Jämställdhetens pris. Boréa, Umeå

- Komulainen, Sirkka (2007) The Ambiguity of the Child's 'Voice' in Social Research, i: Childhood, 2007/1

- Lindgren, Anne-Li \& Halldén, Gunilla (2001): Individuella rättigheter; autonomi och beroende. Olika synsätt på barn i relation till FN:s barnkonvention, i: Utbildning o Demokrati, 2001/2

- Lundqvist, Åsa (2013): Finanskrisen och de ensamma mammorna: Prekära familjeliv bland förvärvsarbetande mödrar i dagens Sverige, i: Tidskrift for velferdsforskning, 2013/4

- Mason, Jennifer (1996): Gender, care and sensibility in family and kin relationships, i: Holland Janet \& Atkins Lisa (red): Sex, sensibility and the gendered body. Macmillan, London

- Mason, Jennifer \& Tipper, Becky (2008): Being related. How children define and create kinship, i: Childhood, 2008/4

- Morgan, David (1996): Family Connections. An Introduction to Family Studies. Polity Press, Cambridge

· Näsman, Elisabet; Källström Cater, Åsa \& Eriksson, Maria (2008): Perspektiv på barns röster om våld, i Eriksson et. al. (red.): Barns röster om våld. Gleerups, Malmö

- Oakley, Ann (1985): The Sociology of Housework. Blackwell, Oxford

- Parsons, Talcott (1965/1971): The Normal American Family, i: Skolnick \& Skolnick (ed.): Family in Transition. Rethinking Marrage, Sexuality, Child Rearing, and Family Organization. Little, Brown and Company, Borton

- Roseneil, Sasha (2004): Why we should Care about Friends: An Argument for Queering the Care Imaginary in Social Policy, i: Social Policy e Society, 2004/4

- Roseneil, Sasha (2007): Queer Individualization:
The Transformation of Personal Life in the Early 21st Century, i: NORA, 2007/2

- Roseneil, Sasha \& Budgeon, Shelley (2004): Cultures of Intimacy and Care beyond 'the Family': Personal Life and Social Change in the Early 21 st Century, i: Current Sociology, 2004/2

- Roman, Christine (2004): Familjen $i$ det moderna. Liber, Malmö

- Roman, Christine (2013): Struggling to manage in a changing economy: A qualitative study on lone mothers in Sweden. CRFR International Conference: Researching Families and Relationships, Edinburgh 10-12 juni

- Samuelsson, Tobias (2008): Children's Work in Sweden. Linköping Studies in Arts and Science, Linköping

- Sandin, Bengt (2012): Children and the Swedish Welfare State: From Different to Similar, i: Fass, Paula \& Grossberg, Michael (red): Reinventing Childhood After World War II. University of Pennsylvania press, Pennsylvania

- Smart, Carol; Neale, Bren \& Wade, Amanda (2001): The Changing Experience of Childhood. Polity Press, Cambridge

- Smart, Carol (2007): Personal Life. New Directions in Sociological Thinking. Polity Press, Cambridge

- Solberg, Anne (1994): Negotiating Childhood. Nordplan, Stockholm

- Spencer, Liz \& Pahl, Ray (2006): Rethinking friendship: Hidden solidarities today. Princeton University Press, New Jersey

- Thomson, Pat (2008): Children and young people: Voices in visual research, i: Thomson Pat (red.): Doing Visual Research with Children and Young People. Routledge, London - van Every, Jo (1999): From Modern Nuclear Family Household to Postmodern Diversity? The Sociological Construction of 'Families', i: Jagger, G. \& Wright, C (eds.): Changing Family Values. Routledge, London

- Waerness, Kari (1984): The rationality of caring, i: Economic and Industrial Democracy, vol 5 - Weeks, Jeffery; Heaphy, Brian \& Donovan, Catherine (2001): Same Sex Intimacies. Routledge, London

- Weston, Kath (1991): Families We Choose: Lesbians, Gays, Kinship. Columbia University Press, New York

- Wihstutz Anne (2011): Working vulnerability: Agency of caring children and children's rights. Childhood, 2011/4

- Wyness, Michael (2006): Childhood and Society: An Introduction to Sociology of Childhood. Palgrave Macmillan, London 